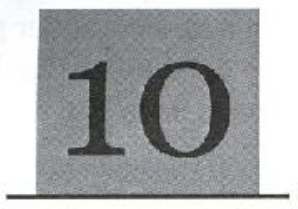

\title{
Climate change: Impacts and threats on freshwater aquaculture
}

\author{
Anyanzu, C. N. / Osuigwe, D. I. / Adaka, G.S.
}

\begin{abstract}
This paper examines the major effects of climate charge on aquaculture, especially on the freshwater ecosystem. Aquaculture as established is not practiced evenly across the world. Therefore, the paper highlights the current aquaculture practices within the regions and across the different environments to ascertain the major effects of cilmate variations on the freshwater ecosystem and aquaculture practices in particular. The main elements of climate change that would impact on aquaculture production, such as sea level and temperature rise, changes is Monsoon patterns and extreme climatic events and water stress, among oihers were' properly looked at and the reasons for their effects udiressed. The different elements of climate change that are experienced in varying degrees can be either pasitive or negative or directly or indirectiy depending on the different culture systems that are practiced. It is in the process of our study that we brought out the complex attributes of cinate change as it affects aquaculture prochuctivity and the possible roles that the society can piay to ameliorate the harsh effecis of ihis ugly monsier, referred to as "climate change and the consequent global warming trends. Keywords: Climate change, freshwater, aquaculture.
\end{abstract}

\section{Introduction}

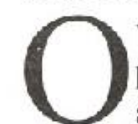

ver the last two decades aquaculture has successfully established itself as a major food source, providing significant proportion of animal protein needs across all communities, irrespective of their living standards. Human food needs and food production are impacted by climate variations and such changes in the eoming decades are a major eoneern, particularly in the developing nations. The threats of climate change to the human society and its natural resources have been given a top priority since the release of the fourth assessment report of the intergovernmental panel on climate change (IPCC, 2007). Recent events showed tendency towards greater extremes in both the arid and the semi- arid regions of Africa, becoming drier with increased magnitude and variability of precipitations and storms (IPCC, 2007). The economics of African countries solely depend on Agriculture, fisheries, forestry and tourism that are increasingly becoming vulnerable to environmental changes. Top on the list of such challenges is climate change that emerged as the most potent threat to sustainable development in $\Delta$ frica (Kalejaye-matti et al., 2010). In the region anthropogenic practices, and in particular energy production and consumption have been intensificd as the main sources of green house gas emissions, though some reports point to the emerging importance of dust as the key factor in climate variability and change most African communities are vulnerable to these impacts mainly due to high poverty levels, reliance on rain- fed agriculture, lack of access to technology, and improved cultural practices.

Climate change defined as change in weather conditions (climate) over period of time consequent upon the natural variability properties or due to human activity is interpreted in many quarters with many scientific data and analysis (Lomberg, 2001). Such data and analysis show that these factors emit green house gases that tend to shade the earth, resulting to Ozone layer depletion, global warming and flooding (MacNeil et al., 1991) climate change being a biophysical process is faced with lots of potential physical and ecological impacts on the aquatic system and the resources as a whole (FAO, 2008). It is expected to result to increased frequency and severity of droughts, floods and extreme weather events that adds to stress on water resources, food security, health, infrastructure and thus overall development (Kalejaiye-matti et al., 2010). Therefore, the focus of African leaders and non-governmental organizations on environment should be on the main streaming adaptation in National planning and support for climate risk management in Africa. They should contribute to mitigation efforts and promote to clean energy development (African partnership forum 2007). 


\section{Scope and Objectives}

Given the background study, this paper based its scope on a desk review of available literature on research reports, books and news papers. Relevant technical literatures on both local and international publications were examined to identify the possible causes of climate change and its adverse effect on Aquaculture practices in Nigeria and the word at larg. This was followed by an appraisal of cach geographical zone through wob search for raising awareness and policy discussions. This paper finally highlights the general impact of climate change on Aquaculture and the mechanism through which climate change may influence aquaculture production systems through various elements of climate variability.

\section{Causes of Climate Change}

Many Authors notably Mackenzic and Mackenzic (1995), UNEP (2002) and TPCC (2007) have extensively written on factors that are responsible for changes in weather conditions. Some of their findings include:

1. Iluman activitics like the burning of fossil fuel, gas flaring and coal fuel, land use practices, especially deforestation leading to the emission of green house gases into the atmosphere which today poses a major problem all over the world. The continued build up of these gases int the atmosphere has led the phenomenon of (ilobal warming. This refers to the persistence increase global temperature due to the green house emitted gases and the dircet effect of the ozone layer depletion due to the absorption of the ultraviolet radiation to the earth surface

2. Other Anthropogenic activities. These include changes in technology as a result of advancement in both the atomic and nuclear bombs and other industrial emissions by man. These changes can increasc to the large emission reaching the earth from the sun which directly widens the orbital parameters on the radiation budget of the earth.

3. Emission of gases duc to volcanic emption. (iases emitted to the atmosphere due to volcanic eruption condense into the almosphere leading to global warming and subsequent solar radiation reaching to the carth from the surn as a result of erosion of the Ozone layer and widening of the orbital parameters also on the radiation budget of the earth.

\section{Effects of Climate Change on Aquaculture}

Climale change effects on aquaculture could occur directly or indirectly or positively or negatively, especially on the natural resources that are necessary for aquaculture. These resources include water land, seed, and feed and encrgy inputs. The first direct effect of climate change on aquaculture dates back to the smog cloud of 2002 El Nino from south- East $\Lambda$ sia. The effect reduces sunlight and heat to the lower atmosphere and the Oceans by ten percent resulting to large dinoflagellate blooms in the coastal areas and severe damage to aquaculture and economic losses worth millions of Naira.

The potential effects of climate change on freshwater aquaculture

- Global warming and temperature increase with associated effects: Global warming effects and temperature rise on pond aquaculture through solar radiation air temperature wind velocity, water turbidity etc result to increase in vaporization, cloud cover and subsequently reduction in solar radiation, reaching the ponds and hence the resultant algal blooms and red tides. On integrated aquaculture the persistence $\mathrm{H}_{5}$ and $\mathrm{II}_{7}$ avian influenza virus strains are feared but the inverse relationship, to temperature and salinity of water reduces this fear of risks to human health (Brown et al., 2006)

- Saline water intrusion: Climate change effects result to sca level rise and increase in salinity intrusion upstream that affects fresh water culture practices. Sea level rise and saline water intrusion will also impose ecological and habitat changes, including the mangroves that serve as nursery grounds for the many curyhaline specics.

- Changes in monsoon patterns and occurrence of extreme weather events: Effects from typhoons, hurricanes and unusual floods increased heavily resulting to large economic losses large storms damaging cage culture systems in rivers and lakes resulting to large escapes of finfishes (Soto ct al., 2001). Climalc change also causes severe weather variability patterns and poor water quality (plankton bloom) resulting to water pollution and other damaging run- off due to flooding that cause structural damage, cscapes and loss of livelihoods of fish farmers

- Water stress: This causes decreased water availability in major rivers and lakes in $\Lambda$ sia and Africa (IPCC 2007). It also causes major effects on fish, which are- spawning, migration and seed availability for large farmers. It can also lead to less water intention time in non perennial water bodies (Goswani et al., 2006)

\section{Indirect effects of climate change on freshwater aquaculture}

- Fish meal and fish oil supplies: I oss of productivity from capture ferneries due $w$ devastarting effects of ocean currents and stomps can pause less raw materials avoid liability for fishmeal and fish oil industry the changes in the ocean circulation patiern will influence fish heat and fish oil supplies (pike and Barlow, 2002).

- Other ingredicnts used in Aquaculture: The use of raw materials, such as soybean meals and corn meals for the production of biofuel instead of usual feed production results to more economic and social challenges, especially in the aquaculture subsector.

- Effects on disease: Increased temperature due to climatc variability, stress the fish and facilitate diseases. In the freshwater aquaculture, increased uptake of toxicants and heavy metals through accelerated metabolic rates from increased temperature by cultured filter feeding mollusks is suggested to be plausible (Ficker et al., 2007), consequently leading to food safety measures and certification issucs. 
- Impacts on Biodiversity: The impacts of climate change on biodiversity from exotic species have resulted to competition for food and space with the indigenous species, in the alteration of habitats (Colleres- Pereira and cowx, 2004), the transmission of pathogenic organisms as well as genetic interactions through hybridization and introgression (Araguas et al., 2004) It is also stated that the genetic makc-up of aquaculture stocks has been altered by selective breeding practices and genetic drift thereby resulting in some instances to severe inbreeding. Such aiterations would potentially impact the gene pools of the wild species with their culture counter parts through genclic alteration, between the escapes and their wild individuals.

\section{Corrective Strategies}

These strategies involve both the adaptation and mitigation strategics employed to reduce the ecosystem vulnerability.

- Mitigation strategies: These are the actions that are taken to prevent, reduce or slow down climate change impacts in our environment. On the other hand, the Adaptive strategies are the actions taken to counteract the adverse effects of climate change. Some of the mitigation strategies include:

- Forest conservation measures that include the prohibition of deforestation encouraging afforestation and rettforestation measures to curtail the emission of green-house gases to the atmosphere.

- Education as a means to creatc awareness to the citizens at the local, state and natioinal levels.

- Adopting measures and programmes to reduce the emission of these gases to the atmosphere by prohibiting the indiscriminate testing of both nuclear and atomic bombs.

- Risk reduction initiatives seeking to addre'ss vulnerabilities through early warning systems timely seasonal weather forecasts, market information systems and disaster recovery programs, informalion and communication technologies arc widely used in fisheries to find already made market and other existing means of dissemination (Cranston and Holmes, 2007).

- Adaptive strategies: The adapttive strategies include:

- Integrating climate issues into economic planning and management at both the national, state and local levels.

- Mobilizing investment through international technology transfer rot facilitate investment into private public power party option for efficiency and reliability and in the petrolcum industry to harness natural gas for both domestic and fossil fuels for generators.

- Discouraging population growth for effective economic and social planning. This will reduce pressure on the available natural resources and also competition for space and survival that cncourages conflicts for land, deforestation etc.

\section{Conclusion}

Climate changed poses a serious challenge to humanity especially in this 21 st century. The severe/Impact to mankind and the resources, has actually threatened our sustainable development and natural resources management. Nigeria as a nation is at great risk or highly vulnerable to imminent climate change impacts as most of our, rainforests are almost gone or completely lost to deforestation and other daily activities by man, such as use of automobiles and machines gas flaring activities, nuclear and atomic energy use and wrong disposal of agricultural and human wastes etc.

The resultant effects will be sea and high temperature riser, global warming same water intrusion and water stress that will impact heavily on our aquatic habitat and threaten the existence of fisheries and agriculture development and production. It is therefore absolute necessary that proactive measures be taken in the areas of mitigation and adaptation strategies to curtail the adverse effect of the changes in our environment due majorly to green-house emission and global warming.

\section{REFERENCES}

African Partnership Forum (APF) (2007). Climate change and $\Lambda$ frica. Briefing paper to. $I$.

Araguas, R.M., Sanz, N., Pla, C.and Garcia-Martin, J.L. (2004). Breakdown of the brown trout evolutionary history due to hybridization between native and cultivated fish. Journal of Fish Biology, 65(Supplement A): 28-37.

Brown, J.D., Swayne, D.E., Cooper, R.J., Burns, R.F. and Staallknecht, D.E. (2006). Persistence of H5 and H7 avian ininflucnza viruses in water. Avian Disease, 50: 236-242.

Collares-Pereira, M.J. and Cowx, I.G. (2004). The role of catchments scale environmental management in fresh water fish conservation. Fisheries management and Ecology, 11: 303-312.

Creanston, P. and Holmes, T. (2007). Uses of information and communication Technologies in Fishing.

FAO (2008b). FAO Fond Outlook 2008. Rome.

Ficke, A.D., Myrick, C.A. and Hansen, L. I. (2007). Potential impacts of global climate change on fresh water fisheries. Reviews in Fish Biology and fisheries, 17: 581-613.

Goswarni, B.N., Venugopal, V., sengupta, D., Madhusoodanan, M.S. and Xavier, P.K. (2006). Increasing trend of extreme rain events in a warming environment. Science, 314: 1442-1445.

IPCC (2007). Climate change 2007. Synihess report, Inter-Governmental panel on climate Change. Also available at www. Ipec.ch/pdf' assessment-report/ar4/syr/ar4-syr-topic/pdf.

Kalejaiye-Matti, R.B., Nassar, S.A., Audu, H.O., Balogun, R.B., Nwoga, R. C. and Garba, B.G. (2010). Proceedings, 44th Annual Conferenec of Agricultural Society of Nigeria, "LAUTECH 2010." 1452-1457. 
Lomborg, B. (2001). The Skeptical Environmentalist: Measuring The Real Sicte of the World. Cambridgc University Press. $511 \mathrm{pp.}$ Mackenzie, F. T. and Mackenzic, J.A. (1995). Our Changing Planet: An Introduction io Earth System Science and Glohal Environmental Change. Prentice Hall, N.J.

Macneill. J., Winsemius, P. and Yakushiji, T. (1991). Beyond Independence: The Meshing of the World's Economy and the Earth's Ecology: A Trilateral Commission Book. Ncw York: Oxford University Press.

Pike, I.H. and Barlow, S.M. (2002). Impacts of tish farming on fish, Bordeaux aquaculture and environment symposium. France. Www: iffo.org.uk/tech /bordeau.htm.

UNEP (2002). The Earth: our common future. First Earth summit of the L.N. Conference on Environment and Develupmcnt (UNCED) Rio de Janeiro, Brazil.

World Bank (1995). Defining an environmental development strategy for the Niger Delta, Vol. Il. Industry and Energy Operations Division (West Africa Dept.) Washington, DC.

Soto, D., Jara, F. and Moreno, C. (2001). Escaped salmon in the imner scas, southern Chile: Facing a ecological conflicts. Ficological Applications, 11/6: 1750-1762. 